University of Rhode Island

DigitalCommons@URI

Open Access Master's Theses

1979

\title{
A COMPREHENSIVE ANALYSIS OF A PRIVATE SECTOR PROGRAM: THE NEW ENGLAND MINORITY PURCHASING COUNCIL
}

Valerie Jean Southern

University of Rhode Island

Follow this and additional works at: https://digitalcommons.uri.edu/theses

\section{Recommended Citation}

Southern, Valerie Jean, "A COMPREHENSIVE ANALYSIS OF A PRIVATE SECTOR PROGRAM: THE NEW ENGLAND MINORITY PURCHASING COUNCIL" (1979). Open Access Master's Theses. Paper 393. https://digitalcommons.uri.edu/theses/393

This Thesis is brought to you for free and open access by DigitalCommons@URI. It has been accepted for inclusion in Open Access Master's Theses by an authorized administrator of DigitalCommons@URI. For more information, please contact digitalcommons-group@uri.edu. 
A COMPREHENSIVE ANALYSIS

OF A

PRIVATE SECTOR PROGRAM:

THE NEW ENGLAND MINORITY PURCHASING COUNCIL

A RESEARCH PROJECT SUBMITTED IN PARTIAL

FULFILLMENT OF THE REQUIREMENTS FOR

THE DEGREE OF MASTER OF COMMUNITY

PLANNING

UNIVERSITY OF RHODE ISLAND

1979 
MASTER OF COMMUNITY PLANNING RESEARCH PROJECT

OF

VALERIE JEAN SOUTHERN

Approved:

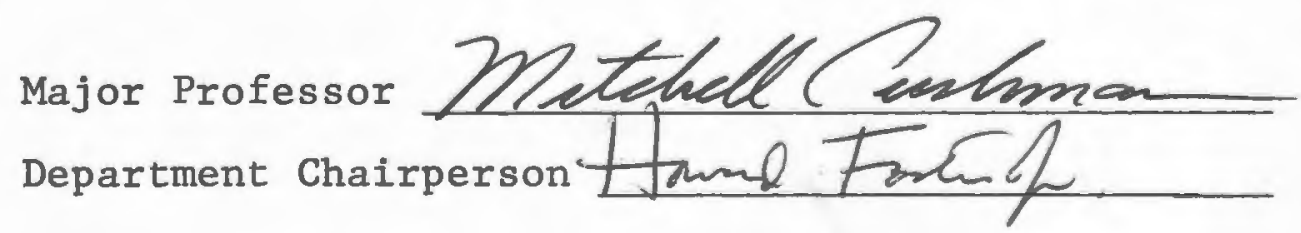

UNIVERSITY OF RHODE ISLAND

1979 


\section{ACKNOWLEDGEMENTS}

A warm thank you to those women and men, listed in Appendix B, for taking precious moments of their busy day to educate and enlighten this writer. Also warm appreciation to Walter Lind, Executive Director of the New England Minority Purchasing Council. The advice and counsel offered by Dr. Glenn Kumekawa and Dr. Mitchell Cushman is also deeply appreciated. And lastly to the minority business women and men of this nation I extend my deepest and lasting appreciation. Their courage, determination and strength can not be denied. 
DEDICATION

This work is dedicated to my family whose attention and faith has always been a blessing.

This work is also dedicated to Eugene Roundtree, President of All-Stainless, Inc. whose presence in the business community indicates that minority business development is more than a goal. It is a gift. 
TABLE OF CONTENTS

$\underline{\text { Page }}$

Introduction

PART I

HISTORY AND PROFILE

Chapter I The State of the Nation.......... 3

Chapter II The New England Minority Purchasing

Council.................. 7

PART II

PERSPECTIVE ANALYSIS

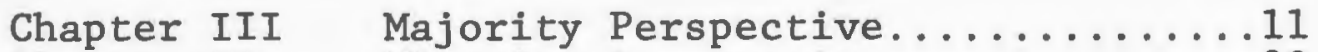

Chapter IV Minority Perspective.............20

Chapter V

Summary and Recommendations......29

PART III

REGIONAL ANALYSIS

Chapter VI Industrial Activity Within Activity

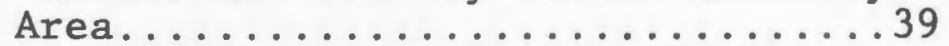

Chapter VII Minority Business Profile Within

Activity Area..............43

Chapter VIII Minority Population Profile Within Activity Area..............46

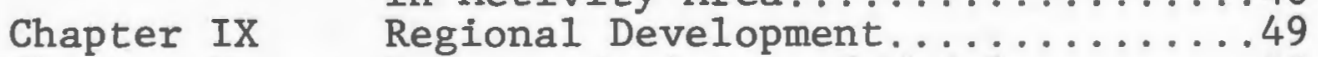

Chapter X Recommendations and Model.......55

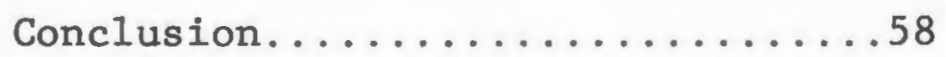

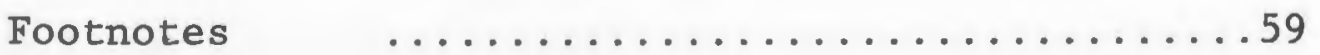

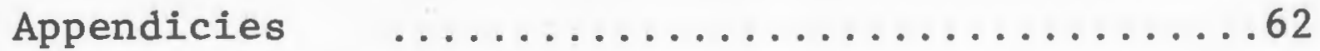

Bibliography...................... 72 
Introduction

This report represents a comprehensive analysis of the performance and efficiency of a regional private sector program.

After a rather inauspicious beginning in 1975, the New England Minority Purchasing Council (NEMPC) has gained acceptance from an increasing segment of the majority and minority business community.

The Council's role and function is to "encourage and facilitate the growth and expansion of minority-owned business by educating and informing purchasers as to the availability of minority-produced products and by increasing the amount of purchasing from minority-owned businesses." 1

The New England Council is one in a network of 35 regional councils across the country, with national headquarters in New York City. A terse history and profile of the development of this program will be offered in Part I. Hopefully, the reader will gain insight as to the political, economic, and racial climate of our nation at the time of NEMPC's creation.

Part II will address and examine the programmatic aspects of the New England Minority Purchasing Council, information and comments will be drawn from forty interviews 
conducted with members, minority clientele, and non-members of the organization. Recommendations for improved service delivery will conclude Part II.

The final segment will address and examine the jurisdictional boundaries governed by the Council. A review of the sociologic, demographic and economic contours of the Council's "activity area" will be rendered so as to properly introduce the concluding chapter; that of recommendation of a regional network. The chapter will advance a model which, if adopted, will increase the program's efficiency, visibility and assist the New England Minority Purchasing Council in accomplishing its long-term objectives. 
PART I: HISTORY AND PROFILE

Chapter I: The State of the Nation

The national and regional network of the Purchasing Council was created as a response to the cry for economic parity from minority business leaders across the nation. The entrepreneurs believed government and business demonstrated more interest in rhetoric and profit than in fulfilling a social responsibility to the under-priviledged masses.

A 1972 Survey of Minority-Owned Businesses released by the Department of Commerce substantiated these "PostWatts" sentiments. It indicated "there were 382 thousand minority-owned businesses in the United States, representing 4.4 per cent of all firms in the country." 2 Blacks at that time accounted for 18 per cent of the total population.

To sharpen the perspective, the average gross receipts of minority firms at that time was $\$ 43,000$. This can be compared to the average for all firms of $\$ 170,000 .^{3}$

The industry characteristics of minority firms further clarified the essentially different position of black business in white America. The census implied that these businesses existed within "isolated markets." 


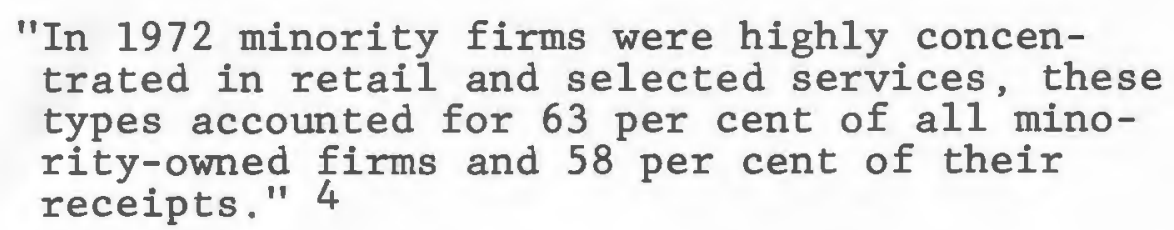

The minority community fared no better. The difference between non-white family income to white family income was 32.5 per cent. Put another way, in 1972 white families in American earned on the average $\$ 3,779$ more in income than non-white. 5

Within the field of business education, of almost 67,000 students enrolled in full and part-time masters programs in business, less than seven per cent were minority; a highly disproportionate number to the 18 per cent of total population. 6

These socio-economic elements provided the proper political setting for another crucial moment in the history of minority business development; the election of President Richard M. Nixon.

Throughout his campaign, the candidate promised to improve the economic condition of the black and other minority masses via a mechanism he termed "black capitalism." The significance of this determination was accentuated in his "Bridges to Human Dignity" radio address: 


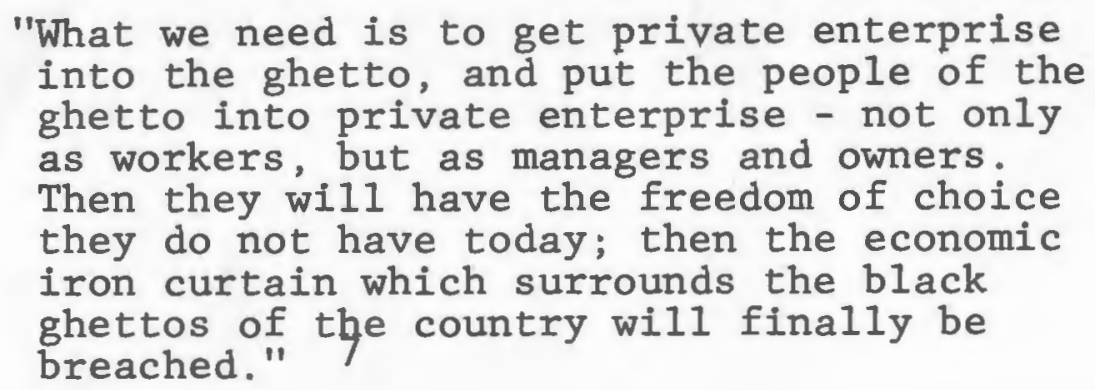

Within months after assuming office the President enacted Executive Order 11458, creating the Office of Minority Business Enterprises (OMBE). The program, placed under the Department of Commerce, became larger than some agencies headed by cabinet level administrators and by 1975 carried a $\$ 5$ billion budget.

In support of this administrative fiat, Secretary of Commerce Maurice Stans announced a milestone goal of doubling the number and activity of minority businesses between 1970 and 1990. Under the auspices of OMBE a score of private and public sectors programs were created, one of which was the semi-public National Minority Purchasing Council (NMPC). Its purpose was to assist the private sector in creating a climate in which to trade with and assist minority business. NMPC is one of the few OMBE funded programs that has survived throughout the years.

On the national level the Council's 110 members represent a cadre of "establishment" corporations and financial institutions. Its chairman, Augustine R. Marusi of Borden Company, 
Inc., this year attributed the purchasing of "\$1.8 billion in goods and services from minority-owned business firms " 8 to the NMPC membership. He states that that figure will double by the end of 1979 and for the year 1980, Marusi has announced a goal of $\$ 3$ billion. 
Chapter II: The New England Minority Purchasing Council

Membership to the New England Minority Purchasing Council has steadily increased from sixty members in November of last year to sixty-eight members in March, 1979.

The Council's central office is located in Cambridge, Massachusetts and is manned by two officers, an Executive Director and Administrative Secretary. Within an operating budget of $\$ 58,000$ (from membership dues and OMBE funds), the non-profit corporation produces a host of programs. These include but are not limited to:

1. Industrial Sales Training Course: this is an intensive three-credit training course for those minority vendors wishing to improve their selling techniques. It is sponsored, in turns, by corporate members. Guest lecturers include Buyers and Purchasing Directors of member firms.

2. Match-makers: an activity wherein a minority firm is sponsored by a majority member. The "host" invites Rlyers from the NEMPC family to attend this "testimonial" wherein the vendor receives plaudit, recommendation, and hopefully increased business from other members. 
3. Buyer Training Program: as the purpose of NEMPC is also to educate the majority business community this activity serves to sensitize and increase the level of awareness of the key Buyers and Corporate nfficers responsible for minority purchasing.

Publications of the New England Minority Purchasing Council include:

1. a listing of 580 minority vendors from within the region entitled the New England Minority Business Purchasing Directory;

2. a "reverse directory" 1isting those majority firms in search of qualified minority vendors;

3. and the Minority Purchasing Resource/Development Program, a guide elucidating the essential elements in developing a corporate minority purchasing program.

The organizational structure encompasses the positions of Executive Director, Board of Directors, and Advisory Committee (minority business representatives,) and a smattering of functional sub-committees. 
NEMPC has at its disposal the resources of private and public member corporations such as the City of Boston, the Federal Reserve Bank, Digital Equipment, Inc., and Arthur D. Little, Inc. ${ }^{*}$ Combined assets of the total membership is estimated to be well over $\$ 20$ billion. $* *$

This year the Council has set as a minority purchasing goal $\$ 30$ million worth of goods and services. It is also in search of new membership as well as new, innovative approaches to furthering the cause and concept of the Council.

* See Appendix A, List of Total Membership $* *$ Combined assets of two member firms alone equal $\$ 13$ billion. 
PART II: Perspective Analysis

In this section the reader will have the opportunity to meet some of the key actors associated with the New England Minority Purchasing Council.* Chapter III will begin with the sentiments of sixteen Buyers and Directors of Purchasing Departments; their successes and frustrations in actualizing the goals set forth by the Council. Chapter IV will conversely present the minority perspective. Here the viewpoints of sixteen minority Vendors will be presented; their experiences in working with Council members. The conclusions of both viewpoints will be presented in Chapter $V$, followed by recommendations.

* See Appendix B for List of Interviewed Majority and Minority Firm Representatives. 
Chapter III: Majority Perspective

"We want to prove to the world (that) business can do this without 40 pounds of legislation. "We ${ }_{9}$ can possibly do it better without regulations." 9

The tenacity expressed in the above statement is an accurate reflection of the sentiment felt by most of the majority actors interviewed for this report.* Today their firms, due to a surfacing social consciousness and strict, often confusing, federal mandates treat minority business as "business un-usual."

They are adjoining themselves to the New England Minority Purchasing Council and embracing the philosophy that "minority purchasing is good business." Along with an avid philosophical support they are also realizing that successful minority purchasing requires a copious amount of commitment and planning. It demands special skills and knowledge.

Forty-four per cent of the respondents joined the Council "to broaden our minority vendor base." Other needs emerged however, such as a need to strengthen their minority purchasing programs and a want to tap information flows related to the subject.

*NOTE: Due to the sensitivity of the issues herein discussed, the respondents will not be directly identified. 
In essence, the need to comprehend the "state of the art" of minority business development is another valid reason for joining the NEMPC family.

TABLE I Reasons for Joining the New England Minority Purchasing Council - Majority Firms

\begin{tabular}{lc}
$\frac{\text { Reasons }}{\text { To Broaden Minority Vendor Base }}$ & 44 \\
$\begin{array}{l}\text { For Assistance in Developing Firm } \\
\text { Minority Purchasing Program }\end{array}$ & 31 \\
$\begin{array}{l}\text { To Advance the Cause and Concept } \\
\text { of Minority Busines Development }\end{array}$ & 25 \\
To Spend Dollars with Minority Firms & 19 \\
$\begin{array}{l}\text { To Be Part of a Collective Majority } \\
\text { Effort }\end{array}$ & 13 \\
For Information & 13 \\
\hline
\end{tabular}

* Due to more than one response per respondent, percentages do not total 100 .

All of the respondents said their firms have experienced an "increase" in minority procurements but most were reluctant to report actual dollar figures.

So as to clarify what is meant by an "increase" an Average Annual Percentage Increase Table was constructed, based on the 1-to-3 year dollar figures reported by four (25 per cent) of the sixteen corporations: 
TABLE II Average Annual Percentage Increase In Minority Purchasing - Majority Firms

\begin{tabular}{|c|c|c|c|c|}
\hline \multirow[t]{2}{*}{ Year (s) } & \multirow{2}{*}{\multicolumn{2}{|c|}{ Dollar Increase }} & \multicolumn{2}{|c|}{$\begin{array}{l}\text { Average Annual Increase } \\
\text { Per Majority Firm }\end{array}$} \\
\hline & & & Per & cent \\
\hline $\begin{array}{l}1975-1978 \\
1977-1979 \\
1977-1979 \\
1978-1979\end{array}$ & $\begin{array}{r}\$ \\
67,000 \\
76,000 \\
385,000\end{array}$ & $\begin{array}{l}0-150,000 \\
0-201,000 \\
0-145,000 \\
0-403,000\end{array}$ & & $\begin{array}{r}33 \\
100 \\
46 \\
05 \\
184\end{array}$ \\
\hline TOTAL AVERAGE & E ANNUAL & PERCENTAGE & INCREASE & $46 *$ \\
\hline
\end{tabular}

Based on the findings in Table II, it is assumed that a member firm, on the average, experiences an optimum 46 per cent increase in the procurement of minority goods and services each year.

Let us now examine what is necessary, what are some of the difficulties in obtaining this level of minority purchasing activity.

\section{Experiences}

When asked what were some of the problems, the Buyers responded as follows:

* Average Annual Percentage Increase Per Firm $=184$ $184 \div 4$ yields Total A.A.P.I. $=\underline{46}$. 


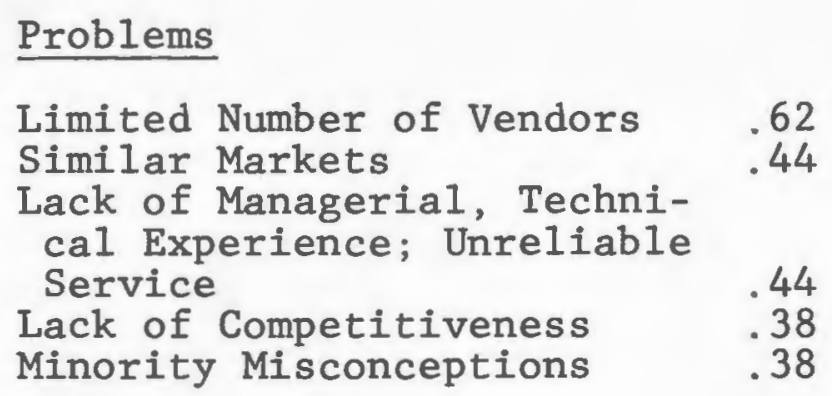

"We don't have enough minority vendors," complained a Purchasing Director of a large manufacturing firm. The few vendors that do appear, if not offered a promise of business then and there "tend not to come back." The Director has taken up the unusual habit of driving to minority vendor shops. In this way he is able to evaluate the validity and efficiency of the operation first hand as well as impress upon the vendor a sincerity in wanting to capture minority trade.

A Supervisor of General Purchasing said he is less concerned with numbers and is more interested in development. In 1975 when the corporation faced new federal equal opportunity legislation "we had to lend ourselves to the situation." Today, though the number of his minority vendors has increased only slightly, their contract dollars have multiplied.

The Supervisor initially offers a small but manageable contract to a minority Vendor. If this is performed satisfactorily, that contract is enlarged. Eventually the minority 
operates on a scale comparable to that of a white Vendor.

The process "increases their competitiveness and our willingness to continue their services. This is the way to get off the ground," the Supervisor said, "you make Vendors."

Minority business in Massachusetts is highly concentrated in retail trade ( 25 per cent) and selected services (43 per cent). 10 "They (minority firms) have a tendency to congregate into certain areas," explained a Director of Management Services. His firm purchases "anything from soup to nuts" but high volume purchases are in packaging, chemicals, machinery, construction and trucking. The Director encourages visiting Vendors to enter these markets.

This perspective is legitimized in the findings of a study of corporate procurement needs conducted by the Small Business Development Corporation in 1978. After surveying twenty-one Buyers, it concludes:

\footnotetext{
"The majority of existing businesses are in service industries such as janitorial work, printing, services, and retail outlet. .

The demand of majority corporations is not being met from the minority sector.

Due to the lack of minority businesses in certain high demand areas where firms spend a large percentage of purchasing dollars, only a small portion. . of total purchasing funds goes to minority firms." 11
} 
A Senior Buyer of a research firm said his supervisors are "profit conscious," thus making it difficult to meaningfully trade with most minority companies. Because of the scale of these firms they are less competitive than larger, well-established white firms. This search for competitiveness is legitimized in a recent issue of Purchasing magazine. It states the "price problem" is quite real regardless of the kind of purchasing:

\footnotetext{
"Suppliers are in for a rough year. Customers will demand more and will re-examine longstanding relationships to make sure their continuation is justified. The reasons (are).. the cost of money, the profit squeeze, shrinking market growth,

and the desire of individual companies to 12 grow regardless of market conditions."
}

Another perplexing concern is that of the misconception held by minorities as to the Purchasing Council's role and function, said a former Board of Directors member and Director of Materiels. He bluntly expressed a desire to "nuzzle the cry babies," those "unscrupulous" vendors seeking automatic trade, regardless of quality and performance. The Director said, despite his firm's need for minority Vendors, he seeks "astute, professional and precise performance" and will not waver from this standard. 
Another Director believes the misconceptions stem from the early years of Council development; "the first years were spent on organizing," mapping directions and establishing goals. The minority Vendors wrongly assumed that the Council at that time was "an organized front," capable of meeting their needs. The Director prophecizes :

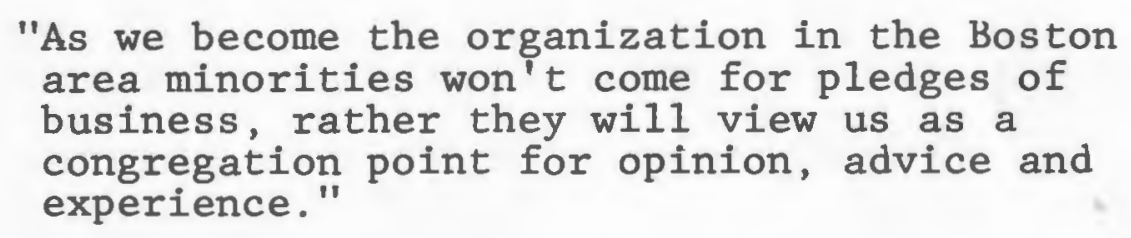

Another concern is that of limited managerial experience and unreliable service. A Purchasing Director of an education and research facility cited " a terrible series of problems" resulting from a long-term contract with a local minority supplier. At times the supplier "did a remarkable job," he said, but when the owner was elsewhere "the company fell to pieces; the organizational depth was not that good and their defenses were off." To resolve the problems the Purchaser initially offered advice, then issued warnings and eventually terminated the contract.

"He never came to me and said these are my problems . . can you help me," the Director said. 
Because of the fear of receiving poor quality products and service, which may result in a disruption in corporate operations, a Director said his Buyers "tend to give lowrisk orders, so we don't fall apart if they fail."

A Vice President believes minority "mis-management" is due to an inadequate "academic business background," making it difficult for the minority entrepreneur to compete with today's college-trained white businessperson.

Generally the Directors and Buyers turn to the Minority Purchasing Council for assistance. The various programs sponsored by NEMPC offer a means to talk over their difficulties and to consider solutions.

A Table of Member Participation in council activities is presented below:

TABLE III Participation in Programs Sponsored by the New England Minority Purchasing Council Majority Firms

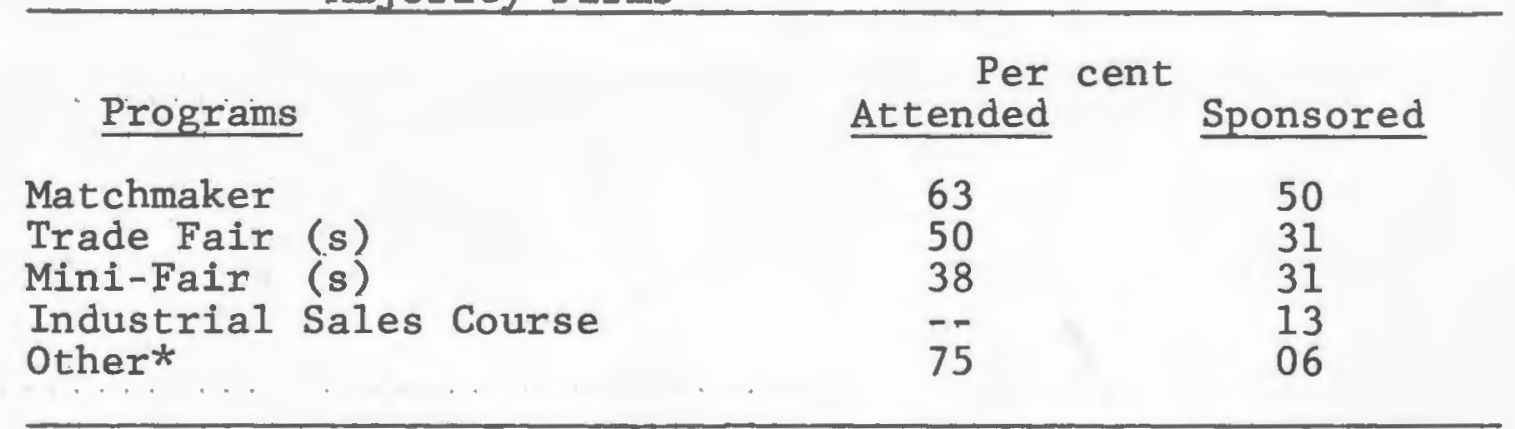

*Other: Buyer Training, Quarterly Coordinator Meetings, Committee Meetings, Board of Director Meetings, Formal and Informal Gatherings. 
The members believe the most effective aspects of the Council are:

$\begin{array}{ll}\text { Programs } & .50 \\ \text { Match-makers(.25) } & \\ \quad \text { Mini-fairs (.13) } & \\ \quad \text { Buyer Training(.06) } & \\ \text { Sales Training(.06) } & .44 \\ \text { Identifying Minority Vendors } & .31 \\ \text { Interaction Among. Purchasers } & .31 \\ \text { Information Source } & .13 \\ \text { Directory Minority Firms } & .06 \\ \text { Assisting Minoriding } & \\ \text { Guidance in Structuring } & .06 \\ \text { Minority Vendor Program } & .06 \\ \text { Stimulating Ideas/Concepts } & \end{array}$


Chapter IV: Minority Perspective

"Sometimes you've got to holler!" 13

Though most of the minority actors agree with the vivid sentiment presented above, there is an ambivalency as to the effectiveness of the New England Minority Purchasing Council.

Sixty-nine per cent of those surveyed indicated an increase in firm sales. They hasten to add however that maintaining a lasting business relationship with a major company is more often than not a frustrating experience.

TABLE IV: Sales Increase Attributed to the New England Minority Purchasing Council - Minority Firms

Q - If your firm experienced an increase in sales was this in part, due to the New England Minority Purchasing Council?

\begin{tabular}{ll} 
Yes & .69 \\
No & .25 \\
NA & .06 \\
\hline
\end{tabular}

$Q$ - If 'YES,' what percentage?

Percentage Increase $\quad$ of Firms With Increase

$20 \quad 09$

$30 \quad 46$

$55 \quad 09$

$60 \quad 09$

Unable To Determine 27 
Based on the construct it is assumed that the Council has attributed an approximate 30 to 35 per cent increase in minority sales activity.

\section{Experiences}

The problems and frustrations encountered by the Vendors are multi-faceted. The most frequent are:

\section{Problems}

$\begin{array}{ll}\text { Insincerity of Majority Firms } & .56 \\ \text { Limited Dollar Commitment } & .50 \\ \text { Limited Time Commitment } & .19 \\ \text { Being "Used" by Majority } & .19\end{array}$

"Member companies claiming avid participation in the Council's programs should have their records checked," commented one minority Vendor. Another suggested that the Council "eliminate corporations that are not serious." The Vendor feels some of the members do not work with fidelity in achieving Council goals; that the corporation join the organization "in name only."

The Vendor believes Council management should conduct and make available "vendor ratings." This method of minority firms evaluating the performance of majority firms "could save everyone a lot of leg work," he said.

Fully 69 per cent of the respondents agreed that stiff performance criteria should be imposed upon present and future member corporations (for example, present and future 
members must purchase at least five per cent of total goods and services from minority firms.) The minority executive would also like to see "a cop on the block," an authority making sure "dollars exchange hands." This minority perspective is based on the Vendor's day to day experiences with Buyers and Directors of member corporations; experiences which they say are often stressful and unprofitable.

More than one respondent cited the example of being awarded a long-term contract yet never receiving the total or full contract value. They believe the corporations nonetheless include the unused dollar figures in their minority purchasing reports to the Council. One Vendor bitterly accounted the experience of being asked by a member firm to bid as well as demonstrate his firm's floor products. After employing extra workers and spending several hours preparing 10,000 square feet of floor space, the Vendor did not receive the contract nor did he receive an explanation as to why his firm was not the awarded firm.

The Vendors are also weary of "check list inquiries." Here a Buyer calls for a bid quotation so as to fulfill a requirement of the corporation's minority vendor program. The procedure drains the limited resources of a minority firm; 
"it takes up a lot of unnecessary time," a Vendor commented, " especially if they're going to go with their regular supplier anyway."

"Some Buyers feel giving an opportunity to bid is in itself an affirmative action," offered a minority executive. He believes the bidding procedures are not reasonable:

"It's like trying to enter into a ring with a heavy weight champion, and you're a feather weight. You're bound to lose."

Rather than arbitrarily extend invitations to small, less competitive firms, the Vendor suggests that major firms determine the capability of a small business and award on a capability basis. In this way, he said, both will profit: the majority company will develop a meaningful relationship with a minority company; the latter has an opportunity to perform a manageable contract.

Because the Council has accepted the large responsibility of enhancing minority business development, many of the respondents believe members must develop unconventional "supplier-buyer" alliances. They should "try to work out a plan with a minority company," offered a Vendor, "(they) should act like big brothers." 
This concept was addressed at the National Minority Purchasing Council's Annual Conference in 1978. Economist Andrew Brimmer leveled a caveat to the conferees stating that the headway made by minority entrepreneurs over the years is fragile and will erode due to:

1. migratory patterns of the minority population from the central city;

2. erosion of the black businessperson's traditional markets;

3. and lack of minority representation in fast growth industries.

Brimmer encourages major companies to extend deliberate aid and assistance to minority firms:

"I believe each of the leading corporations in this country should seek to develop a 'family relationship' with one or more minority-owned firms. This linkage might be perceived as a 'brother-brother, sister-sister, or godfathergod-child' relationship.

Once the relationship is established, the central corporation can use its great variety of resources to promote the growth and development of business owned by members of minority groups. . . .through deliberate and imaginative efforts -- reaching beyond the rather passive role of purchasing a modest amount of readily available goods and services -- significant new opportunjties for minority firms can be created." 
Brimmer postulates that "family ties" between major and minority firms are necessary in the areas of:

1. Management Assistance,

2. Intermediate and Long-Term Contracts,

3. Operations and Quality Control,

4. and Finance: Equity Capital and Long-Term Loans.

The economist also encourages major firms to develop "spin-offs" wherein minority enterprises are created vis-avis corporate management's identification of talented and capable minority employees.

"Spin-offs" are not new to the Council. In 1968 the management of the TWR Carr Division (a member firm) negotiated cost, feasibility, management and market needs with a willing and capable minority employee. Together the parties formed an alliance and "created" the Americans, Black and White Company (AB\&W), a minority manufacturing firm producing precision metal stampings and fasteners. Another Council member, the Shawmut Bank of Boston, provided the finance for the merger.

Today AB\&W has sales of $\$ 1.2$ million and is owned and operated by minority management. The President, Jesse L. Vailes, says of the business success:

\footnotetext{
"We were determined to prove that a black-operated manufacturing company could make it in the competitive American system. We wanted to show that color is no factor in what people can do - that blacks also take pride in their work. We believe we've overcome the doubts." 15
} 
Vailes believes that "alliances" are pragmatic and profitable but he also cautions interested parties to conduct a long-term and comprehensive analysis of the proposed venture; "you can't just give a plant and inventory to someone, there is a lot more," he warns.

Over the years the firm developed with constant nurturing from the "parent" corporation. TWR Carr Division management offered quality control assistance, long-term trade, management assistance and other such resources throughout the infancy and growth phases of the minority enterprise. 


\section{Industrial Sales Training Course}

Fifty per cent of the minority actors believe the Course was very helpful, 38 per cent somewhat helpful; and 12 per cent provided no comment.

TABLE V: Experiences of Participants In Industrial Sales Training Course - Minority

Experience Per Cent of Respondents

Pointed Out Key Selling Techniques 69

Introduced Me To Rey Buyers 44

Offered Opportunity To Discuss Problems 38

Highlighted My Strengths and Weaknesses 38

Did Not Cover My Needs* 19

Did Not Offer Solutions To Problems 06

Too Long 13

Too General 06

Other** 19

*Needs: Telephone Interview, Appearance, Follow-up, Presentation, Discussing Product Line Un-familiar To Other Students, Dealing With Insincere Buyers.

**0ther. Did Not Stick To Text, Need Minority Instructors, Not Related To Needs and Problems of Small Business, Not Long Enough, Need Course Follow-Up.

Note: Due to more than one response per respondent, percentages will not total 100 . 
Of the topics covered in the course, the following were considered to be most helpful:

1. Stress Placed On Persistance,

2. Presentation Methods,

3. Introduction Methods,

4. Dealing With Objections,

5. Determining Needs of Customer,

6. Time and Territory Management. 
Chapter V: $\quad$ Summary and Recommendations

Clearly, based on the viewpoints of the different actors there exists a disparity in perception as to the effectiveness of the New England Minority Purchasing Council. On one hand, the majority members believe the insufficient numbers, attitude and inabilities of the minority firms hinder goal attainment. On the other hand, minority Vendors believe the members are not trying; that they are insincere in their pledge to assist in minority business development.

So as to determine a commonality in opinion as to the direction the actors believe the Council should take, a Common Goals Table was constructed: 
TABLE VI: Common Goals Table Majority - Minority Firms

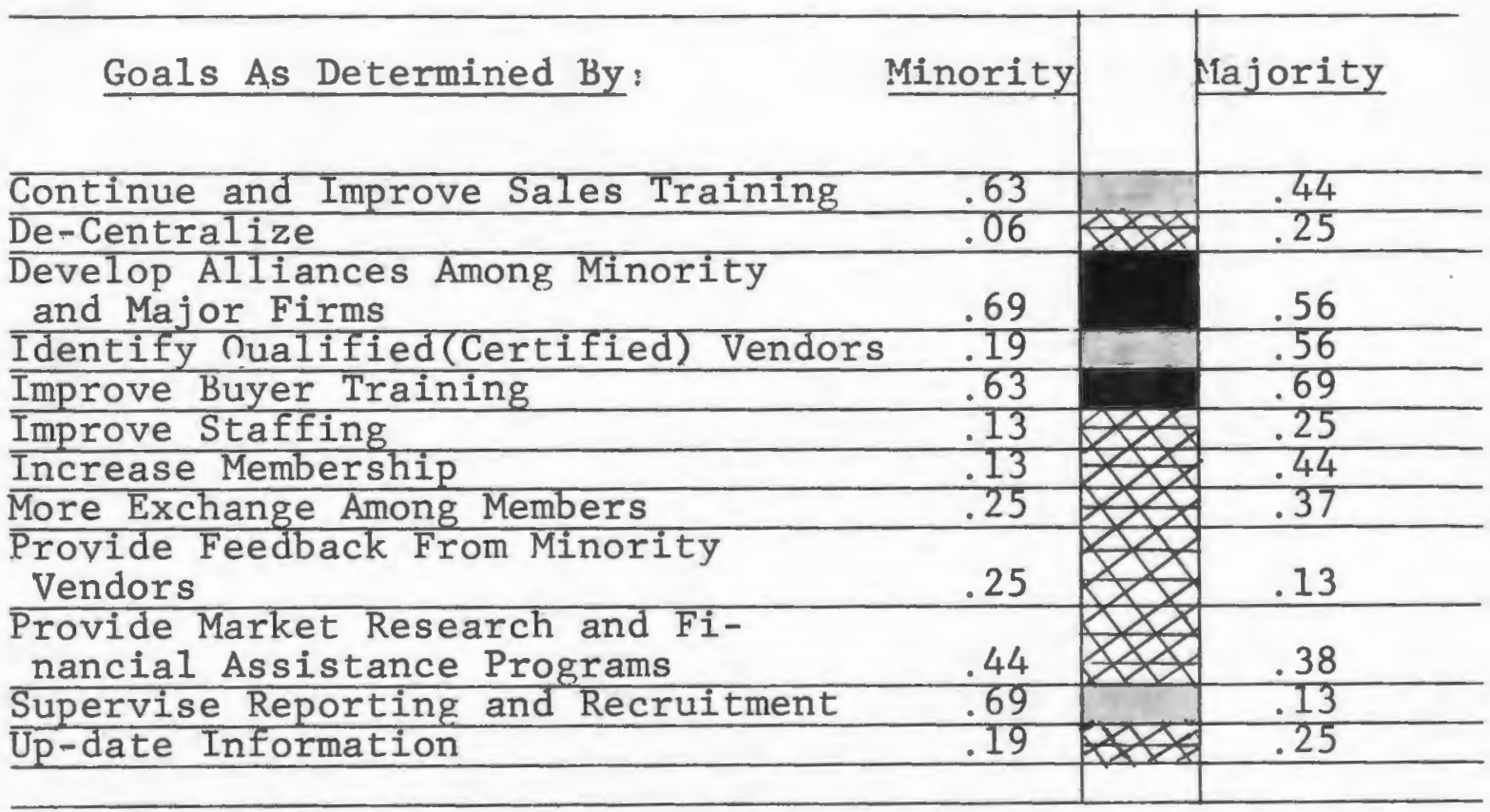

Most Common Area of Agreement

Moderate Area of Agreement

Mixed

Goal for Minority, Not Emphasized by Majority

Goal for Majority, Not Emphasized by Minority 
In summary the Council in its three and one-half years of life has marshalled the resources of a retinue of minority firms and major corporations for the purpose of assisting in the socially redemptive cause of minority economic development. In the years to follow this time in history the organization must mend the differences of the various actors within its range of responsibility. and provide an atmosphere in which the trade of goods and services becomes commonplace among black and white business within New England.

To accomplish this the Council must recognize that the socio-economic and political elements of the past stand as a pre-requisite to the challenges of the present and the future. The minority viewpoint is one that portrays a constant and cautious search for dignity and economic equality. The majority is one of recognition of this search. Both require a focal point; a fertile ground in which to mature and fully develop.

The Council's primary challenge is to provide choice and innovation in the decision-making activities of its membership and minority clientele. It is hoped that the following recommendations will assist in this endeavor. 


\section{Recommendations}

Based on the findings of this research project the following recommendations are put forth:

1. that the New England Minority Purchasing Council place great emphasis in resolving the potentially harmful and self-defeating differences in opinion and attitude which presently exist among its members and minority clientele.

As demonstrated in the Common Goals Table, the actors themselves have singled out key components for achieving improved lines of communications:

1. Education (Improved Buyer and Sales Training)

2. Intra-Personal Relationships (Alliances Between Minority and Majority Businesses.)

The Council should pursue these areas with all deliberate speed so as to alleviate further disparity in group opinion and emphasis. Other suggested methods for improved communications are:

1. round table discussions,

2. field surveys - such as that conducted in this project,

3. on-site visitations to majority and minority firms,

4. and inclusion of an 'Opinion Column" or 'Letter to the Director" section in the Council newsletter. 
2. that the New England Minority Purchasing Council revise its present member reporting system so as to more fully capture the effort put forth by majority companies as well as more fully determine organization direction and scope.

Presently the system provides information as to the amount of minority dollar purchases within and outside of the New England activity area. This should be revised so as to:

1. determine the advertisement effort utilized by the majority firms in capturing minority trade;

2. determine the time commitment necessary in achieving corporate and organization goals;

3. provide a listing of those contracts successfully and unsuccessfully performed by minority vendors with explanation and remarks;

4. determine innovative measures.undertaken by members to assist or trade with minority concerns;

5. and of most importance, provide a listing of the type and kind of minority purchasing contracts awarded.

If, for example, it is demonstrated that a large number of contracts are granted in the field of Selected Services, a collaborative effort should begin so as to promote or "create" alternative minority enterprises within demanded and lucrative markets.

3. that the New England Minority Purchasing Council in

planning future Industrial Sales Training Courses make

a greater effort to enlist minority instructors and

lecturers. 
Role-models create a sense of believability to most meaningful classroom experiences. It is suggested that the Council draw from the pool of past Minority Sales Training Graduates and also from the various business development agencies within the State.

4. that the New England Minority Purchasing Council continue its efforts to bring talented minority student personnel to the agency. However, in addition to recruiting business students, it is also suggested that students learned in the fields of economics, accounting, planning, law, insurance, and other such disciplines be considered so as to match resource with need.

5. that the New England Minority Purchasing Council clearly define the role and function of the existing Advisory Council.

As the Advisory Council exists presently, its minority members serve on an "as needed" basis. This body should be assigned long-term responsibilities which will further the cause of the entire organization. Suggested areas of responsibility are:

1. Research and documentation of issues affecting the development and growth of minority business enterprises;

2. Creation and sponsorship of programs and activities which will further stimulate communications among the minority and majority firms; 
3. Implementation of a mechanism in which a "reverse" Purchasing Council may be created. Here the Advisory Council could provide a means for trade of goods and services from minority business to minority business. In this charge the spirit of minority business development would be realized.

Other recommendations for Council consideration are:

1. up date the Council charter. This document describing the cause and function of the organization should reflect the ever-changing structure and thrust of the organization.

2. up date information publications. The Minority Business Purchasing Directory should 1ist certified and existing minority enterprises.

3. lastly, so as to comprehensively pursue long range development strategies, the New England Minority Purchasing Council should develop a regional plan wherein utilizing the vast resources within its activity area. This subject is addressed in the final segment of this report. 
PART III:

$\underline{\text { Regional Analysis }}$

Introduction

Despite its title, the New England Minority Purchasing Council's activities are primarily concentrated within the State of Massachusetts, rather than within the six-state New England region.*

In the state the writer has identified and boundaried six contiguous areas or regions so as to present an understandable profile of what is now termed the NEMPC "activity area." (See Figure I, Page 37: Spatial Distribution of Activity Area.)

The areas are:

Region I: Berkshire, Franklin, Hampshire and Hampden Counties;

Region II: Worcester County

Region III: Middlesex and Norfolk Counties

Region IV: Essex County

Region V: Suffolk County

Region VI: Plymouth, Bristol, Barnstable, Duke and Nantucket Counties.

* The Council operates two branches in Connecticut and Rhode Island; both however maintain marginal productivity. 
FIGURE I: Spatial Distribution of New England Minority Purchasing Council Activity Area.

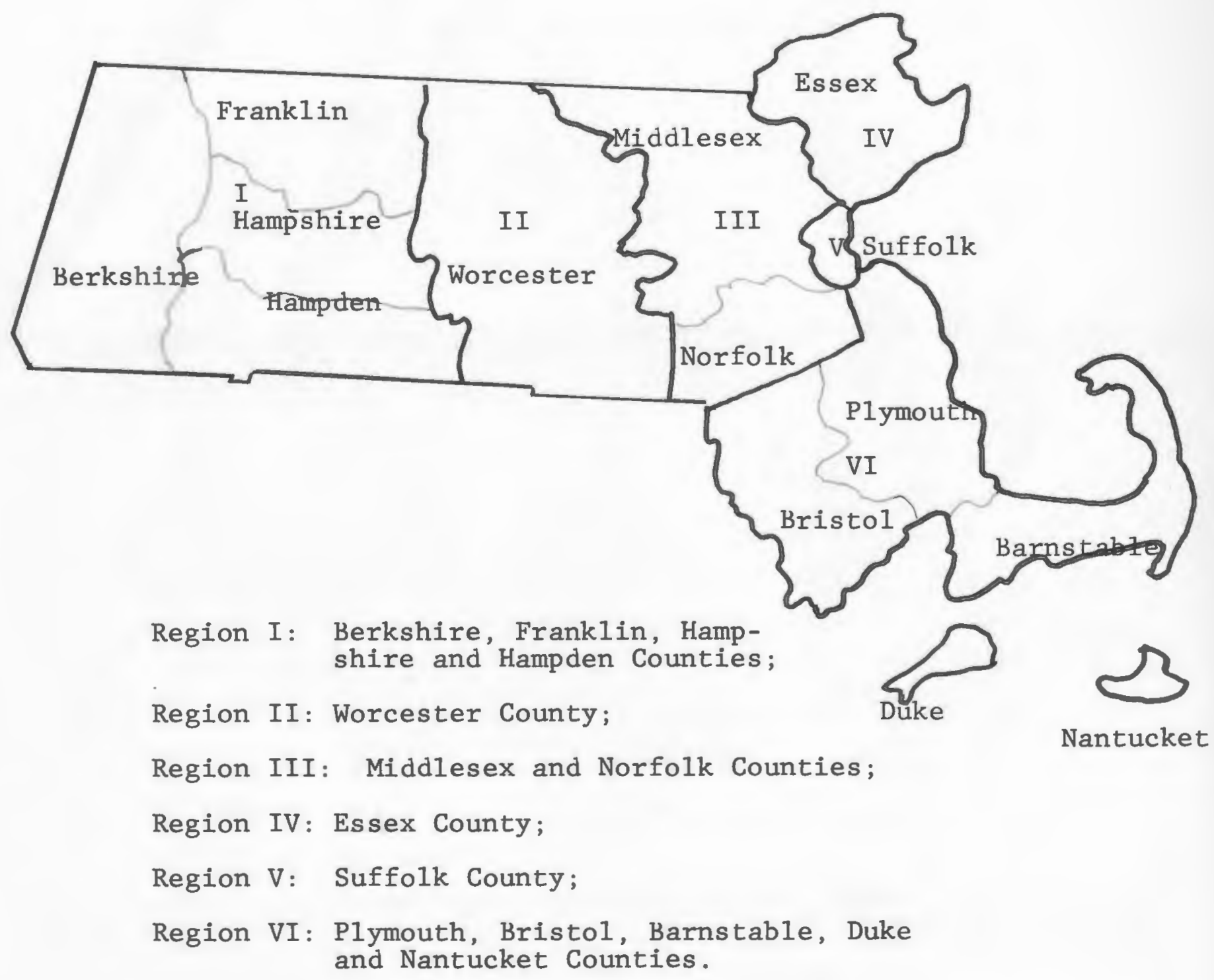


In these regions are "common characteristics tied by extensive interareal activity or flows." 16 or put another way, in them exist separate yet common activities which, if applied within a regional context, may provide clarity and foresight to the comprehensive tasks the Council has yet to accomplish.

Chapter VI will begin with a profile of industrial activity currently taking place within each region. Chapter VII shall examine the nature and distribution of minority enterprises within each region followed in Chapter VIII with a similar review of the regional distribution of the minority population .

This analysis represents a beginning; an initial step in identifying and dissagregating the complex jurisdictional terrain which the New England Minority Purchasing Council is chartered to serve. 
Chapter VI: $\quad$ Industrial Activity Within Activity Area

"Propulsive" growth centers or poles are those entities within an economic and "geonomic" space which extend

economic influence over a particular region. 17

Within the activity area, ten such centers have been identified. They hold 85 per cent of the population within the state and 88 per cent of the employment opportunities. 18 These centers of labor, manufacturing, population and trade are by region:

\section{Growth Center}

1. Pittsfield

2. Springfield-Chicopee-Holyoke

3. Fitchberg-Leominster

4. Worcester

5. Lowe11

6. Lawrence-Haverhill

7. Boston

8. Brockton

9. Fall River

10. New Bedford

\section{Region 非 of Firms}

$\begin{array}{lrr}\text { I } & 1,799 \\ \text { I } & 9,304 \\ \text { II } & 1,808 \\ \text { II } & 6,842 \\ \text { III } & 2,950 \\ \text { IV } & 3,983 \\ \text { V } & 55,839 \\ \text { VI } & 2,519 \\ \text { VI } & 2,545 \\ \text { VI } & 3,171 & \\ & & \\ & 90,760 & \text { TOTAL }\end{array}$

SOURCE: Department of Commerce and Development, The Commonwealth of Massachusetts Monograph; 1976; Revised.

Thus for membership recruitment purposes or for an identification of high industrial concentration per region, one may devise the following ranking system: 
\begin{tabular}{ccc} 
RANK & REGION & 非 of Firms (Within Growth Center) \\
\cline { 2 - 3 } 1 & V & 55,839 \\
2 & I & 11,103 \\
3 & II & 8,650 \\
4 & VI & 8,235 \\
5 & IV & 3,983 \\
6 & III & 2,950
\end{tabular}

This however is not and should not be the sole means for determining industrially active "pockets" within the activity area. Another reasonable indicator of economic activity and growth is the number of industrial expansions per region. Region III leads in this area with 51 firm expansions, creating 1,842 jobs. A breakdown per region follows :

\begin{tabular}{|c|c|c|c|}
\hline Region & $\begin{array}{l}\text { In-State } \\
\text { Expansions* }\end{array}$ & $\begin{array}{l}\text { Job } \\
\text { Creation }\end{array}$ & $\begin{array}{l}\text { Total } \\
\text { Square Footage }\end{array}$ \\
\hline I & 13 Firms & 270 & 234,868 \\
\hline II & 20 & 337 & 430,000 \\
\hline III & 51 & 1,842 & $1,535,700$ \\
\hline IV & 21 & 991 & 369,530 \\
\hline V & 4 & 250 & 193,000 \\
\hline VI & 22 & 1,665 & 720,700 \\
\hline
\end{tabular}

*Expansions from July, 1978 through December, 1978.

SOURCE: Massachusetts Business Relocations and Expansions; Executive Office of Economic Affairs, Department of Commerce and Development, Boston, MA, 1978.

During the five-month reporting period, those firms realizing the greatest expansion in operations were per region: 


\begin{tabular}{cllllc} 
Region & Name of Firm & Location & \multicolumn{1}{c}{$\begin{array}{c}\text { Total } \\
\text { Sq. Ft. }\end{array}$} & \multicolumn{1}{c}{$\begin{array}{l}\text { Job } \\
\text { Creation }\end{array}$} \\
\cline { 1 - 1 } I & Dialectrics, Inc. & Chicopee & & 35,000 & \\
II & Nypro, Inc. & Clinton & 60,000 & 20 \\
III & Digital Equipment* & Bedford & 215,000 & 400 \\
IV & Norelco & Lynn & 117,000 & 30 \\
V & PX Engineering & Boston & 65,000 & 40 \\
VI & Datel Systems & Mansfield & 114,000 & & 450
\end{tabular}

SOURCE: Massachusetts Business Relocations and Expansions, Executive Office of Economic Affairs, Department of Commerce and Development, Boston, MA, 1978.

Here again a clear identification is rendered as to where industrial growth and expansion is taking place within the regions and who is responsible for that industrial growth; thus making recruitment efforts and jurisdictional analysis meaningful and rational. This process is known as resource development and will be discussed in detail in Chapter IX of this report.

In sub-state regional planning, each region is perceived as a distinct yet contributing segment to the whole. This is true of each district's or region's product output or indigenous manufacturing characteristics. This is demonstrated in the following table:

* Member of the New England Minority Purchasing Council. 
$\begin{array}{ll}\text { TABLE VII: } & \text { Manufacturing Output Per Region Within } \\ & \text { New England Minority Purchasing Council } \\ & \text { Activity Area }\end{array}$

REGION

Manufacture Output

I

Electric and electronic equipment, paper and allied products, fabricated metal and machinery (except electrical)

II

Fabricated metal products, stone, clay and glass products, plastics and resins and machinery (except electrical.)

III

Machinery, electric and electronic equipment and textile mill products

IV

Electric and electronic equipment, instruments and related products, leather and leather products

$\mathrm{V} \quad$ Electrical machinery, instruments, and related products

VI

Apparel and finished goods, textile mill products, rubber products, paper and allied products, leather and leather products, instruments and related products and machinery.

Council representation within each of these districts or regions will assist in determining where minority firm creation or development should take place as well as what minority produced product or service will prove most lucrative within a given geographical market.

* Underlined indicates those products unique to the region. 
Chapter VII: Minority Business Profile Within Activity Area

The 1972 Census of Minority-Owned Business Enterprises reported 2,990 such firms in Massachusetts with gross receipts of $\$ 146,000.20$ These firms constitute approximately 2.7 per cent of all business in the activity area; one per cent less than the minority population percentage. Minority firms in Massachusetts are highly concentrated in Selected Services and Wholesale Trade. Table VIII presents a comparative analysis of total business to minority business within industry concentrations.

TABLE VIII: Comparative Analysis of Industry Concentration of Minority Firms to Total Business in Area

$\underline{\text { Business }}$

Construction

Manufacturing

Transportation and Public Utilities Wholesale

Retail

Finance, Insurance, and

Rea1 Estate

Selected Services

Other Industries

TOTAL
Total

12,938

10,071

4,243

9,485

31,494

$$
8,455
$$

31,836

2,111

110,633
Minority

334

91

133

58

734

174

1,272

194

$2,990(2.7 \%$ of Total)

SOURCE: U.S. Department of Commerce, 1972 Census, The Commonwealth of Massachusetts Monograph, published by the Massachusetts Department of Commerce and Development, revised 1976, and the State Office for Minority Business Assistance, Boston, MA. 
Data pertaining to the geographical distribution of minority firms was compiled from zip code listings of those firms served by the State Office of Minority Business Assistance (SOMBA). This listing is legitimized by SOMBA's adherence to federal and state guidelines for identification of minority business.* The data offered by the organization represents a universe of 1,015 firms or 34 per cent of all minority business within the state.

Region I (Suffolk County) holds the greatest number of minority-owned firms, Region II (Worcester County) the least. A geographical distribution of minority enterprises within the activity area is presented in Figure II, Page 45.

This process of indentifying the spatial distribution of the NEMPC target group will assist in determining where minority firms are located and where emphasis should be placed in policy formulation and recommendations for the Council membership and management.

* Fifty-one per cent ownership and control by a minority member constitutes and defines a "minority-owned "business. 
FIGURE II: Geographical Distribution of Minority Businesses Within NEMPC Activity Area*

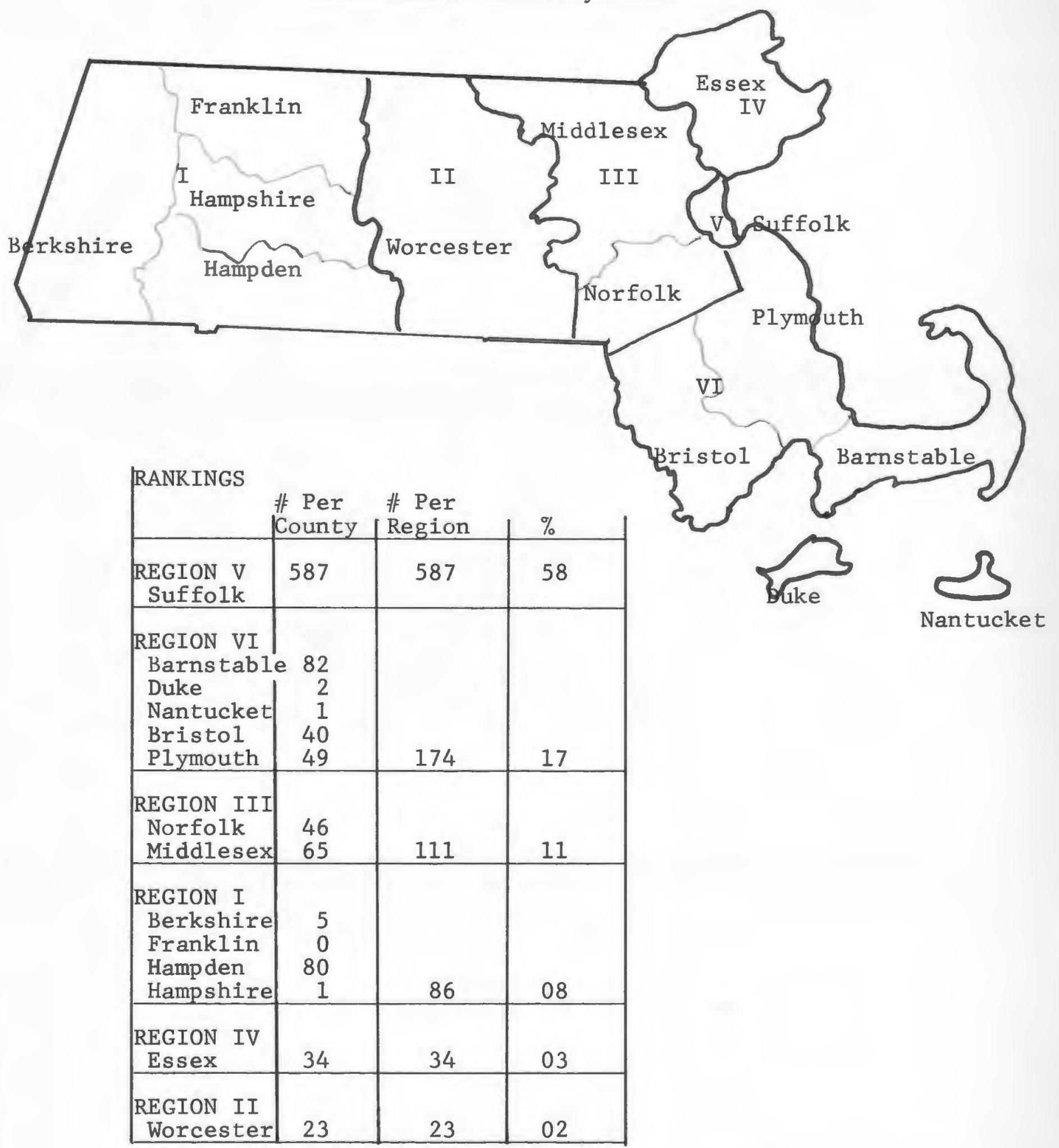

*Universe - 1,015 Firms (34 per cent of total)

**Source: State Office of Minority Business Assistance, Boston, MA. 
Chapter VIII: Minority Population Profile Within Activity Area

There are 213,050 minority residents within the New England Minority Purchasing Council activity area, representing 3.7 per cent of the total population. 21 The greatest concentration (55 per cent) reside in Region V, Suffolk County, the least (03 per cent) in Essex County, Region IV. Geographical distribution by region of this populous is presented in Figure III, Page 47 of this report.

There are twenty-one cities and towns with minority populations greater than the state average. Those of particular significance are Boston (18.2 per cent minority population), Cambridge (8.9 per cent), Hyannis ( 4.7 per cent), Ayer Center (6.5 per cent), Ayer ( 8.5 per cent), Harvard (9.9 per cent), South Lancaster ( 8.9 per cent) and Springfield (13.1 per cent). 22 These minority population "pockets" provide fertile breeding ground for the growth and development of minority enterprises and may serve as target areas for education and training programs sponsored by the Council.

The 1970 Population Census Survey reveals the fact that 56 per cent of the minority population actively participates in the Massachusetts labor force as compared to 88 per 
FIGURE III: Geographical Distribution of Minority Population Within NEMPC Activity Area*

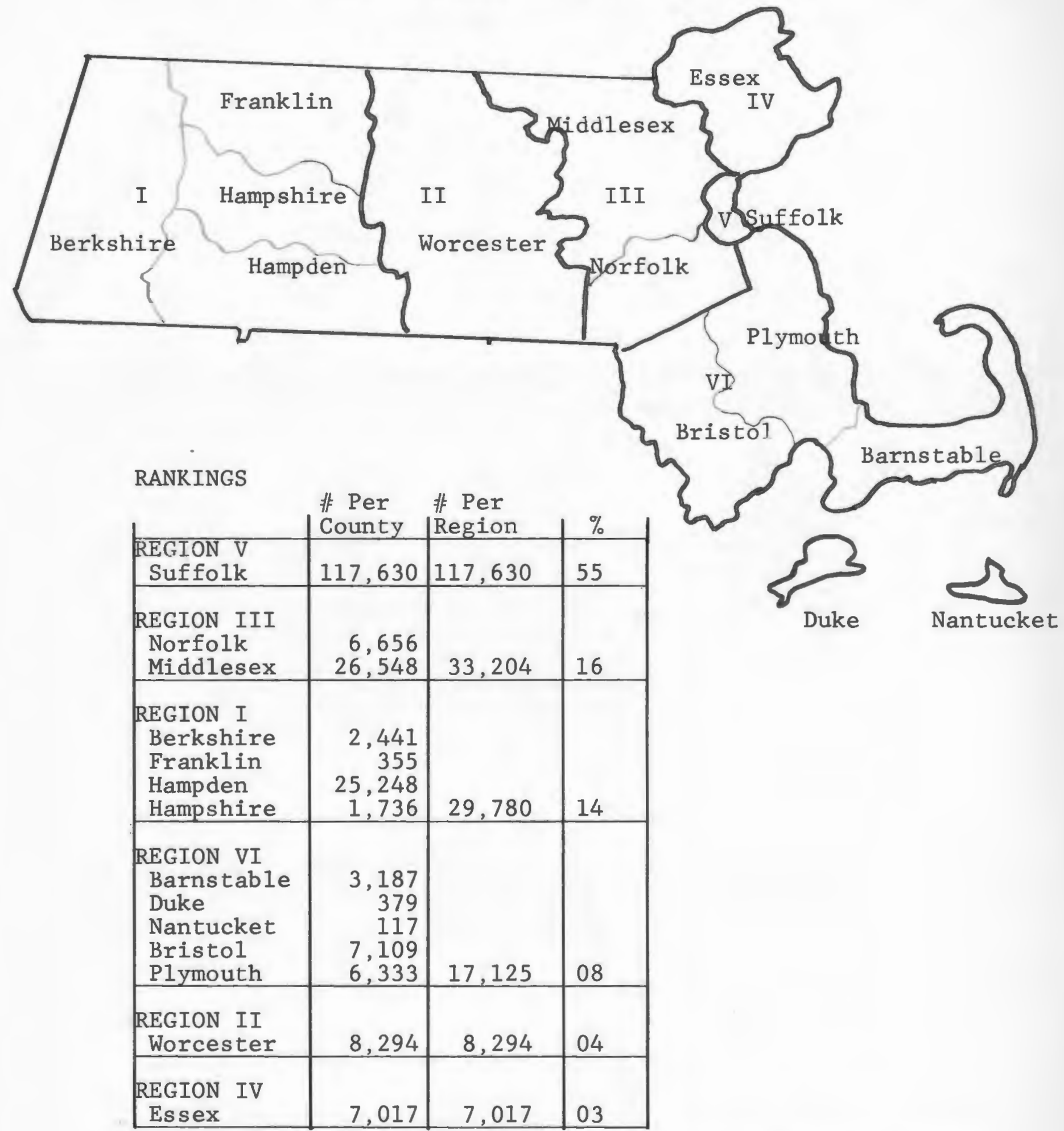

*Source: U.S.Department of Commerce, Bureau of Census, 1970. 
cent participation by whites. Occupations of employed blacks are concentrated in the categories of Operative (20 per cent), Clerical and Kindred Workers (20 per cent) and Service Workers (20 per cent).

The industries in which Massachusetts minorities are employed are primarily manufacturing, with a dominance in electrical machinery, equipment and supplies (26 per cent), Hospitals (09 per cent) and Elementary/Secondary Schools and Colleges (06 per cent). 23

This profile provides clues as to the occupational skill level of minorities within the activity area. The high percentage of workers within the electrical machinery and equipment category implies that in this industry there may be candidates for minority entrepreneurship (providing there is the proper mix of incentive, finance, managerial/ technical skill and market demand.) 
Chapter IX: Regional Development

Based on the information presented in the preceeding chapters, a strong case may be made for sub-state regional planning and resource development within the New England Minority Purchasing Council activity area.

Before recommendation of a functional delivery system is put forth however it is important to first understand "sub-state regionalism" - what is meant by it.

The New England Minority Purchasing Council in its present form operates via a "central core" theorem in that activity, policy, development and emphasis promulgates from within an urban (propulsive) center within Region V. Growth proceeds in a concentric fashion to Region III and Region IV. This is demonstrated by the high concentration of member firms, 47 per cent, in Region V; the second highest concentration, 29 per cent, in Region III, along the periphery of the former. (See Figure IV, Page 50 for a geographical distribution of membership.)

The underlying notion of "central core" or centralized development is that a balance or equilibrium in activity is not desired, rather the core influences and dominates. While this method has merit in that slow, controlled growth is better than no growth at all, it is best suited for central city or closed system planning. 
FIGURE IV: Geographical Distribution of New England Minority Purchasing Council Membership Within NEMPC Activity Area.

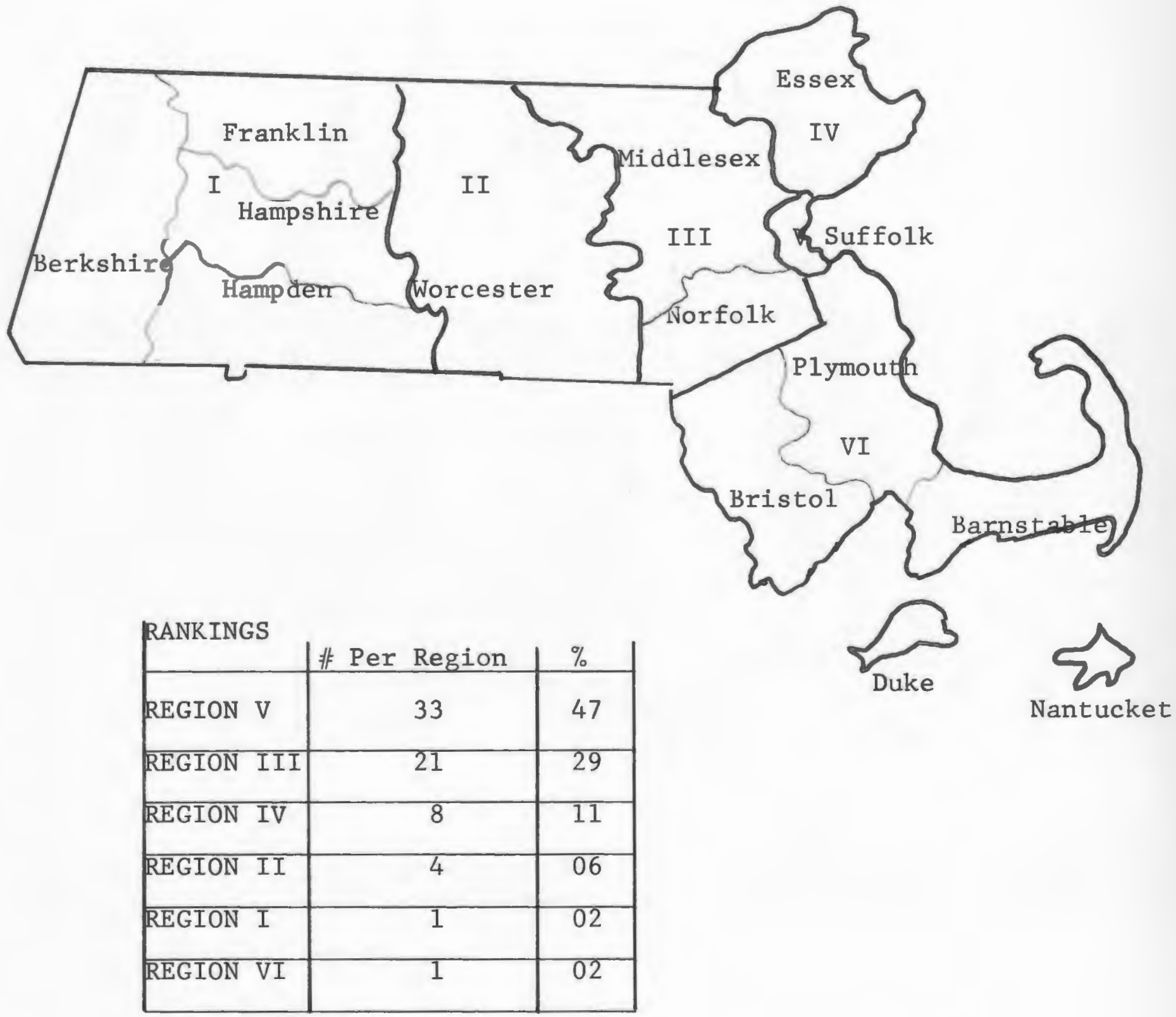

*Total Membership - 68 
Application of this method to a regional function serves to narrow that function and role; handicapping the functional capabilities of other regions within NEMPC's broad jurisdiction.

Sub-state regions - for our purpose those areas identified in Figure I - may be defined:

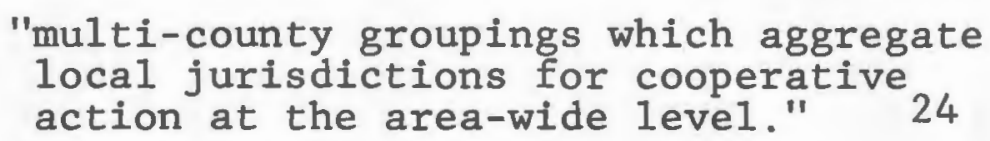

These sub-state regions, if comprehensively planned and coordinated, have the great potential to assist the New England Minority Purchasing Council in creating an equilibrium of emphasis throughout the activity area; an equilibrium which presently does not exist. The inter-locking necessity for coordination, comprehensive and sub-state regional planning is presented in the following statement issued by the Advisory Commission on Inter-Governmental Relations:

\footnotetext{
"The purpose of comprehensive planning is to inject information and method into the process of policy and program development. This helps to assure the rational determination of priorities and relationships among programs, and the coordination of activities in order to serve the broad purpose. This connection between comprehensive planning and coordination at a strategic or convenient sub-state district level is a major reason for the development of sub- 25 state regionalism." (Emphasis Added)
} 
In a less long-winded but similar support of coordinative sub-state regional efforts, economist David L. McKee states one "can not decide what, without first knowing where." 26 
Chapter X: $\quad$ Recommendations and Model For Regional Development

The New England Minority Purchasing Council is actively seeking new membership and rightfully so for this initiative will bring support, visibility and diversification to the program.

It is recommended that future recruitment efforts be a.) uniform throughout the region and b.) targeted in those areas which demonstrate stable and certain growth. As presented in Chapter VI, "propulsive" centers and expansion areas are evenly distributed throughout the region. Recruitment of members should be directed to those areas and firms demonstrating vitality and growth; those firms committed and capable of providing resources and services to the Council.

It is recommended that all programs developed for the benefit of the minority entrepreneur (i.e. "spin-offs," divestures, long-term contracts) be a.) comprehensively planned so as to realize full utilization of available resources and b.) located uniformly throughout the activity area; those areas of ideal location where minority and majority firms (mute to propulsive) may be effectively matched. 
It is also recommended that education and training programs be located and planned in areas where "pockets" of the target population are strongly represented and that these programs also be uniformly distributed throughout the activity area.

Whether in the recruitment of majority firms, in the training of Buyers within the region, or in providing minority business expansion and growth efforts, a rational, purposeful and regional approach is tantamount to the Council's successful matching of capability, need and resources.

Functional Delivery System

"An analyst is perplexed with many problems when he looks at a region. One problem may be to identify specific industries which can individually or in groups operate efficiently and with profit in the region. Another related problem may be to improve the welfare of the people in the region. . . achieve a more equitable distribution of income.

Another pressing problem. . is the problem of how to put to best use a limited, if not niggardly, endowment of resources." (Emphasis Added.)

Vinod Dubey,

"Definition of Regional Economics"

The Council's resources are presently "clumped" within the Boston metropolitan area. For extensive growth to be realized in a rational and systematic fashion it is recommended that the Council join to the present organizational 
structure a "Council of Regional Representatives." (NOTE: this may also replace the present Board of Directors.) In this form the Council will indeed function as a regional council. Each member would be responsible for the long-term goals of a.) membership recruitment b.) expansion of a minority vendor base and c.) promulgation of innovative programs within his or her jurisdictional terrain. Each member would have an understanding and sensitivity to his or her particular district and thus would be most capable of determining goals and capabilities and resources held within that region.

A graphic depiction of the "Council of Regional Representatives" is illustrated in Figure V, on the following page. 
FIGURE V:

COUNCIL OF REGIONAL REPRESENTATIVES

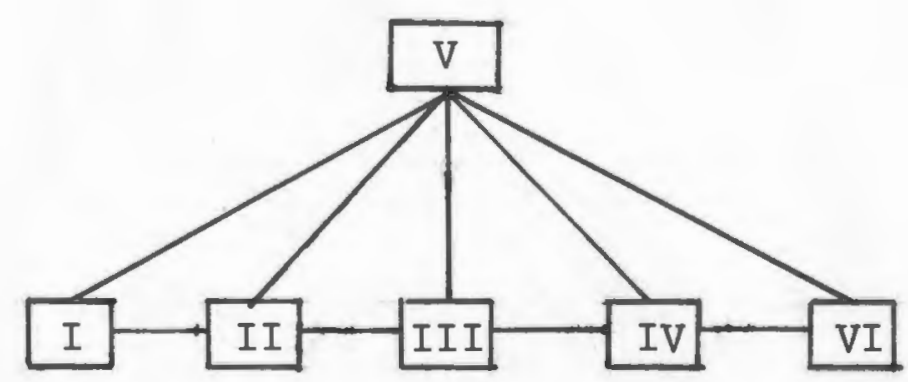

Each member shall represent a total, harmonious and collective effort. Each member is responsible for creating a NEMPC presence within his or her region. Each member is responsible for:

1. membership recruitment;

2. expansion of a minority vendor base;

3. programs and functions within his or her designated region.

Each member shall ascertain:

1. capability;

2. resources;

3. and goals and commitment for his or her region. 
The Council would continue to be served and directed by the Executive Director, representing Region V.

It is believed that if the New England Minority Purchasing Council adopts this model, it will be successful in accomplishing its long-term endeavors. Further this method may be applied to the entire six-state New England region, bringing together representatives from each state; representing a coordinated and comprehensive multi-state effort. 
CONCLUSION

This report has offered to the reader a documentation of the past, several interpretations of the present and an optimistic look into the future for the New England Minority Purchasing Council. In that it is a study of the Council as an organization and as a function, it contains recommendations which are primarily directed to the management of the Council and its membership.

This however does not imply that the challenge of improving the status of minority business is solely that of the New England Minority Purchasing Council. There is much work to be done by the minority entrepreneurs as well. These individuals must strive to form strong alliances within the minority business community; they too must reckon with and dissipate the socio-economic forces which, not long ago, alienated them from the economic marketplace and the free enterprise system.

In essence, both parties must accept the reality that one can not and will not accomplish its goals without the mutual respect and cooperation from the other. If this thesis is accepted, the effort put forth in this project has been worthwhile. 
FOOTNOTES

1. Articles of Incorporations; New England Minority Purchasing Council; Cambridge, Massachusetts; 1975; Article IA.

2. Survey of Minority-Owned Business Enterprises, 1972; Bureau of Census, Special Report; United States Department of Commerce, Social and Economic Statistics Administration; Washington, D.C.; 1975; Page 1.

3. White House Conference on Balanced Growth and Economic Development; Issues of Minority Business Development; Prepared by the Office of Minority Business Enterprises and United States Department of Commerce; January, 1978; Pages 2 - 4.

4. Survey of Minority-Owned Business Enterprises, 1972;

5. White House Conference On Balanced Growth and Economic Development; Page 2.

6. Report of the Task Force on Education and Training for Minority Business Enterprises; United States Department of Commerce and Office of Minority Business Enterprises; Washington, D.C.; 1974; Page 21.

7. Doctors, Samuel I.; Minority Enterprise and the President's Council; Ballinger Publishing Company; Cambridge, Massachusetts; 1973; Pages 2 and 3.

8. ACCESS, "Marusi Outlines Council Goals; " United States Department of Commerce and Office of Minority Business Enterprises; Washington, D.C.; November/December, 1978; Page 8.

9. Van Nostrand Jr., Reeves M.; Assistant Vice President, The First National Bank of Boston; Boston, Massachusetts; March, 1979.

10. Survey of Minority-Owned Business Enterprises, 1972; Bureau of the Census, Special Report; United States Department of Commerce, Social and Economic Statistics Administration; Washington, D.C.; 1975; Page 32. 
11. Gordon, Helen; Future Growth Industries: Survey on Investment and Business Opportunities for Minority Entrepreneurs and Individuals; Small Business Development Corporation; Boston, Massachusetts ; 1978; Page 3.

12. "Buyers won't be paying premiums for sentiment;" CEO Report; Purchasing; New York; January, 1979; Page 95.

13. Ceasar, Eugene; President, American Industrial Supplies; Brockton, Massachusetts; April, 1979.

14. Brimmer, Andrew F.; Economic Growth, Market Shares and Prospects for Minority-Owned Businesses; Brimmer \& Company, Inc.; Washington, D.C.; October, 1978 ; Pages 16 and 20 .

15. Vailes, Jesse L.; President, Americans, Black \& White Company; Dorchester, Massachusetts; April, 1979.

16. Perloff, Harvey; Regions, Resources and Economic Growth; Introduction: A Note on Regions, Time and Growth Measures; University of Nebraska Press; 1967; Pages 2 and 3.

17. Darwent, D.F.; Growth Poles and Growth Centers in Regional Planning; Alonzo and Friedman; MIT Press; Cambridge, Massachusetts; 1964; Page 539.

18. The Commonwealth of Massachusetts Monograph; Department of Commerce and Development; Boston, Massachusetts; $1976 ;$ Page 8 .

19. The Commonwealth of Massachusetts Monograph; Op Cit.

20. Survey of Minority-Owned Business Enterprises, 1972; Bureau of the Census, Special Report; United States Department of Commerce, Social and Economic Statistics Administration; Washington, D.C.; 1975; Page 32.

21. Census of Population, 1970; General Population Characteristics in Massachusetts; United States Department of Commerce, Bureau of the Census; 1970; 23-47.

22. Ibid; $23-47$.

23. Ibid; $23-245$.

24. Perloff, Harvey; Regions, Resources and Economic Growth; Introduction: A Note on Regions, Time and Growth Measures; University of Nebraska Press; 1967; Pages 2 and 3. 
25. Advisory Commission on Inter-governmental Relations; Regional Decision-making; New Strategies for Sub-State Districts; Washington, D.C.; 1974; A-43.

26. Mckee, David L.; Regional Economics; The Free Press; New York; 1970; Page 136.

27. Ibid., Page 8 . 


\section{APPENDICIES}

\section{APPENDIX}

A

New England Minority Purchasing Council Membership

B

Majority and Minority Firm Representatives Interviewed/Surveyed

C

Questionnaire Form - Majority Firms

D

Questionnaire Form - Minority Firms 


\section{APPENDIX A}

New England Minority Purchasing Council Membership

1. Addison Wesley Publishing Company, Inc.; Reading, MA

2. Allyn \& Bacon; Boston, MA

3. American Optical Corporation; Southbridge, MA

4. Amstar Corporation, Boston, MA

5. Anderson Nichols, Boston, MA

6. Arthur D. Little, Inc.; Cambridge, MA

7. Avco Everett Research Laboratory, Inc.; Everett, MA

8. Avco Systems Division; Wilmington, MA

9. Blue Cross/Blue Shield of Massachusetts; South Boston, MA

10. Bolt Beranek and Newman Inc.; Cambridge, MA

11. Borden Chemical Company; North Andover, MA

12. Boston Edison Company; Boston, MA

13. Boston Gas Company; Boston, MA

14. Cabot Corporation; Boston, MA

15. CADEC Systems; Littleton, MA

16. City of Boston, MA

17. Coca-Cola Bottling Company of New England; Needham, MA

18. Converse Rubber Company; Wilmington, MA

19. Corning Glass Works; Medifeld, MA

20. Dennison Manufacturing Company; Framingham, MA

21. Digital Equipment Corporation; Maynard, MA

22. Eastman Gelantine Corporation; Peabody, MA

23. Federal Reserve Bank; Boston, MA

24. The First National Bank of Boston; Boston, MA

25. The Foxboro Company; Foxboro, MA

26. General Dynamics; Quincy, MA

27. General Electric Company; Lynn, MA

28. GenRad; Concord, MA

29. The Gilette Company; Boston, MA

30. GCA Corporation; Bedford, MA

31. The Gorton Group; Gloucester, MA

32. GTE/Sylvania, Inc.; Danvers, MA

33. Harvard University; Cambridge, MA

34. Helix Technology Corporation; Waltham, MA

35. Hewlett Packard; Waltham, MA

36. Honeywel1; Brighton, MA

37. Houghton Mifflin Company; Boston, MA

38. Ionics, Inc.; Watertown, MA

39. John Hancock Mutual Life Insurance Company; Boston, MA

40. Liberty Mutual Insurance Company; Boston, MA

41. Massachusetts Bay Transportation Authority; Everett, MA

42. Massachusetts Institute of Technology; Cambridge, MA

43. Massport Authority; Boston, MA 
44. Mead Containers; Gardner, MA

45. Mitre Corporation; Bedford, MA

46. New England Merchants National Bank; Boston, MA

47. New England Telephone Company; Boston, MA

48. Northeast Electronics; Concord, MA

49. Northeastern University; Boston, MA

50. Norton Company; Worcester, MA

51. Ortho Instruments; Westwood, MA

52. Parker Brothers; Beverly $\mathrm{Ma}$

53. Polaroid Corporation; Cambridge, MA

54. Raytheon Company; Lexington, MA

55. RCA/Government and Commercial Systems; Burlington, MA

56. Shawmut Bank of Boston, MA

57. Sprague Electric Company; North Adams, MA

58. Star Market Company; Cambridge, MA

59. State Street Bank \& Trust Company; Boston, MA

60. Stone \& Webster Engineering Corporation; Boston, MA

61. Texas Instruments; Attleboro, MA

62. Textron, Inc.; Providence, RI

63. TRW Carr Division; Cambridge, MA

64. Tufts University; Medford, MA

65. Ventron Corporation; Beverly, MA

66. Western Electric; North Andover, MA

67. Westinghouse Electric Corporation; Hyde Park, MA

68. Wyman-Gordon Company; Worcester, MA. 
APPENDIX B

Majority and Minority Firm Representatives Interviewed and/or Surveyed:

\section{MAJORITY}

1. Arthur D. Little, Inc. - Daniel Leone

2. Avco Everett Research Laboratory - Harold Bloom

3. Boston Edison Company - James Delani

4. City of Boston - Donald Roach

5. Digital Equipment Corporation - Peter Hunter

6. Digital Equipment Corporation - Tal Buckley

7. Federal Reserve Bank - Amy Bizar

8. First National Bank of Boston - Reeve Van Nostrand, Jr.

9. Gilette Company - James Krueger

10. Harvard University - Robert Mullen

11. Harvard University - William Lee

12. Massachusetts Bay Transportation Authority - Robert Newton

13. New England Merchants National Bank - Robert Jackson

14. Norton Company - Raymond Goodale

15. Polaroid Corporation - Charles Cain

16. Textron, Inc. - Joseph Baldasaro

17. Textron, Inc. - Edward Case

18. TWR Carr Division - Thomas Costello

\section{MINORITY}

1. At Secretarial Service - Alvene Williams

2. All Stainless, Inc. - Eugene Roundtree

3. All Stainless, Inc. - Stephen R. Wysocki

4. Allen \& Little Company, Inc. - Joseph Consolino

5. American Industrial and Medical Products, Inc. Amur Kapur

6. American Industrial Supplies - Eugene Ceasar

7. Black \& White Printing Company - Cecilia Thompson

8. Contemporary Multi-Service Corporation - Oscar Wilson

9. Coverdale Associates, Inc. - Shirley Coverdale

10. Harris Chemical Company - Art Harris

11. Hicks Typewriter Service Company Inc. - Robert Hicks

12. Manessa Key Punch, Inc. - Earl Campbel1

13. Metro-Boston Excavation - Oliver D. Fernandez

14. Neale \& Sullivan Inc. - Bruce Neale

15. Phase One Office Products - Reith Castle

16. Southern Enterprise - Kenneth N. Southern

Appendix B Continued, Page 66. 
APPENDIX B CONTINUED

OTHER

1. Arthur Atkins - State Office of Minority Business Assistance

2. Frank Bishpam - Office of Minority Business Enterprises

3. Helen Gordon - Small Business Development Corporation

4. Kern Grimes - Grimes Oil Corporation

5. Ann Elliot - New England Minority Purchasing Council

6. Walter Lind - New England Minority Purchasing Council

7. Leo Welton - - Sales Representative

8. Jesse Vailes - $A B \& W$ Corporation 
Dear Counc1l Member. Thank you for particlpating in this study of the New England Minority Purchasing Counc11. I am a student of the University of Rhode Island Planning Department, completing a Master's Degree. This questionnaire is part of my final Thesis Project, which is evaluating the New England Minority Purchasing Council.

As you are aware, I will be visiting your office shortly. If you have any questions concerning this form, please feel free to discuss your concerns at that time. Thank you in adsance for your time.

1. Name

2. Title

3. Name of your Company

4. What service or product does your company provide?

5. In what year was your f1rm established?

6. What is your flrm's approximate annual sales level? $s$

7. When did you Join the New England Minority Purchasing Council?

8. Why did you foln?

9. In what ways has your firm assisted the councll in achieving its goals? sponsored sales training course (year___ month sponsored trade-fa1rs/minl-fairs/match matchers. increased purchases to minority vendors and suppliers attended programs and activities sponsored by the council. They were: Other:

10. Have purchases from minority vendors and suppliers increased from your firm since Council membershlp ? yes no.

11. If "yes" please give an "before/after" indication of this increase:

Before membershlp we purchased from minority vendors/suppliers. \% of our total goods and services

After membership we purchased from minority vendors/suppliers. \% of our total goods and services 
12. What do you belleve to be the most effective aspects of the New England Minority Purchasing Council?

13. In what areas should the Councll concentrate, for Increased effectiveness?

14. This 18 an optional question. It is not necessary to answer this question, but the information 111 provide further information on the effectiveness of the New England Minority Purchasing Council.

Please list those minority vendors and suppliers in which you have developed a meaningful business relationshlp:

a.)

b.)

c.)

d.)

Thank you for your assistance. Please use the available space for any comments or questions you may have. 
FOR: Graduates of Sales Training Course sponsored by the New England Minority Purchasing Council

FROM: Valerie J. Southern, Candidate: Master's Degree, University of Rhode Island

Dear Graduate,

It would be appreciated if you would take the time to answer the questions on this form. My reason for this request is to evaluate the New England Minority Purchasing Council and its effectiveness in aiding your firm in attaining increased sales from NEMPC members.

You are a graduate of the Sales Tralning Course and an officer of a minority business. Your imput will be invaluable in determining whether the council is accomplishing its goals.

I am a graduate student of the University of Rhode Island. My Thesis Project is the study of the structure and goals of the NEMPC. My particular interest is in the development of the minority firms within New England. Thank you for your assistance.

Part A.

Profile Data

1. Firm Name

2. Product or Service

3. Location of Firm

4. Your Position/Title

Telephone Number

(Zip Code)

(Please include area code)

5. How long has the firm been in operations?

6. How was the firm initially financed?

(If more than one source, please give percentages)

personal capital

Sma11 Business Administration

Minority Enterprises Sma11

Business Investment Corporation

private capital contribution

other (specify, if you wish:

7. How many workers does the firm employ? 
PART B.

Course Evaluation

8. How did you find out about the sales Training Course?

9. When did you complete the Course? Month

Year

10. Did you find the Course to be Very Helpful. Somewhat Helpful Not Helpful

11. Check comments that apply to your class experience:

pointed out key selling techniques.

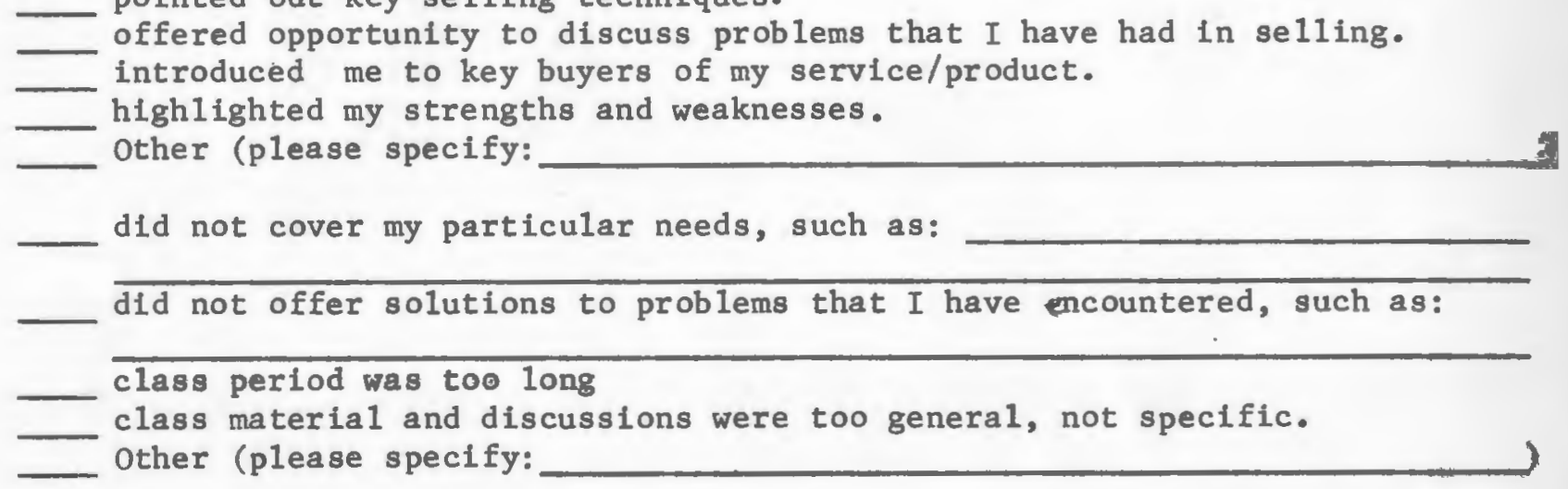

12. Of all the key issues covered in the class, which was most helpful?

PART C.

\section{Impact}

13. On an approximate scale what was your firm's annual sales level BEFORE class participation?

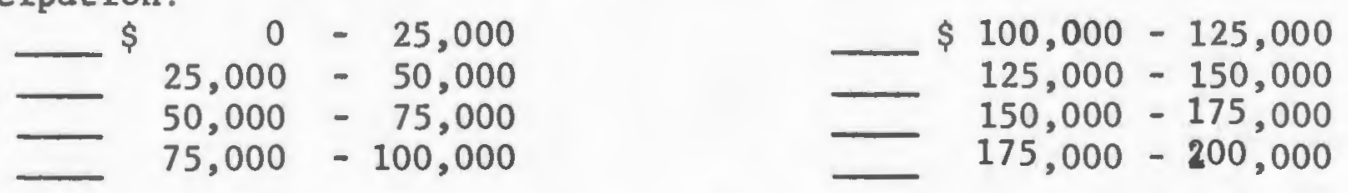

If over $\$ 200,000$, Please give approximate sales level $\$$

14. What was your firm's annual sales level AFTER class participation?

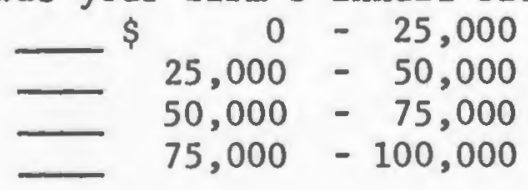

$\$ 100,000-125,000$

$125,000-150,000$

$150,000-175,000$

$175,000-200,000$

If over $\$ 200,000$, Please give approximate sales level $\$$

15. If your firm experienced an increase in sales was this, at least in part, due to the New England Minority Purchasing Council? If "Yes" what percentage? $\%$ yes no.

16. In a brief statement please offer suggestions as to how the NEMPC (New England Minority Purchasing Council) may further accomplish its goals. 
PART D.

\section{Genera1}

This last section is optional. If you chose to answer the questions however, your answers will provide additional pertinant information. Thank you for your help.

1A. What firms have been most helpful in purchasing your service or goods?

$$
\text { (name) (address) (state) }
$$

1.

2.

3.

2A. What firms have not been helpful in purchasing your service or goods?

1.

2.

3.

3A. What reasons did the firms, that were not helpful, give for not purchasing your service or goods?

no reason did, not need my services my prices were not competitive my company was too far away my inventory was too sma 11 Other:

Please specify

4A. What reasons did the firms, that were helpful, give for purchasing you services and goods?

no reason needed my services they wanted a minority supplier my prices were reasonable

Other: Please specify

5A. If you have any comments to make regarding this questionnaire, the New England Minority Purchasing Council or minority business development in general, please comment on the remaining space and on the back of this sheet. Thank you. 


\section{BIBLIOGRAPHY}

BOOKS

Advisory Commission on Inter-Governmental Relations; Regional Decision-Making: New Strategies for Sub-State Districts; Washington, D.C.; 1973.

Bailey, Ronald W.; Black Business Enterprises; Basic Books, Inc.; New York; 1971.

Cook, Gillian; Spatial Dynamics of Business Growth in the Witwatersrand; University of Chicago, Department of Geography; Chicago, Illinois; 1975.

Darwent, D.F.; Growth Poles and Growth Centers in Regional Planning, A Review; Alonzo and Friedman; MIT Press; -Cambridge, Massachusetts; 1964.

Doctors, Samue1 I.; Whatever Happened To Minority Economic Development?; The Dryden Press; Hinsdale, Illinois; 1974.

Doctors, Samuel I.; Minority Enterprise and the President's Council; Ballinger Publishing Company; Cambridge, Massachusetts; 1973.

Ginzberg, Eli; Business Leadership and the Negro Crisis; McGraw-Hil1 Book Company; New York; 1968.

McKee, David L.; Regional Economics; The Free Press; New York; 1970.

McLoughlin, Brian; Urban and Regional Planning, A Systems Approach; Faber and Faber; London; 1969.

Perloff, Harvey; Regions, Resources and Economic Growth; University of Nebraska Press; 1976.

Venable, Abraham S.; Building Black Business, An Analysis and Plan; Earl G. Graves Publishing Company; New York; 1972 .

Yancy, Robert J.; Federal Government Policy and Black Business Enterprise; Ballinger Publishing Company; Combridge, Massachusetts; 1974.

\section{ARTICLES}

Davis, George; "National Minority Purchasing Council, Sharing Corporate Bucks Not Charity But Good Business;" Black Enterprise; New York; December, 1978. 
Gumpert, David E.; "Seeking minority-owned businesses as suppliers;" Harvard Business Review; Graduate School of Business Administration, Harvard University; Massachusetts; January-February, 1979.

Purchasing; CEO Report; "Buyers won't be paying premiums for sentiment;" New York; January, 1979.

Winters, Frank J.; "Minority Purchasing. . . It's Good Business;" National Purchasing Review; New York; January-February, 1979.

Young, Harding B.; "Systems Approach To Black Entrepreneurship; " Business Education Forum; May, 1973.

OTHER SOURCES

Brimmer, Andrew F.; Economic Growth, Market Shares and Prospects for Minority-Owned Businesses; Brimmer \& Company, Inc.; Washington, D.C.; 1978.

Department of Commerce and Development; Commonwealth of Massachusetts Monograph; Boston, Massachusetts; 1976.

Executive Office of Economic Affairs; Commonwealth of Massachusetts; Business Relocations and Expansions; Boston, Massachusetts; 1975 - 1978.

New England Minority Purchasing Council; Minority Purchasing Resource/Development Program; Cambridge, Massachusetts.

New England Minority Purchasing Council; Newsletter; Cambridge, Massachusetts.

; New England Minority Business Purchasing Directory; Cambri dge, Massachusetts.

Office of the Federal Register; Public Papers of the President of the United States; National Archives and Records Service; Washington, D.C. 1970.

Smal1 Business Development Corporation; Future Growth Industries: Survey on Investment and Business Opportunities for Minority Entrepreneurs and Individuals; Boston, Massachusetts; 1978.

State Office for Minority Business Assistance; Zip Code Analysis; Boston, Massachusetts; 1977.

United States Department of Commerce and Office of Minority Business Enterprises; ACCESS; Washington, D.C.; 1978. 
United States Department of Commerce and Office of Minority Business Enterprises; Report of the Task Force on Education and Training for Minority Business Enterprises; Washington, D.C.; 1974.

United States Department of Commerce; Census of the Population; 1970; Massachusetts General Population Characteristics; Washington, D.C.

United States Department of Commerce; Bureau of the Census, Special Report; Survey of Minority-Owned Business Enterprises, 1972 ; Social and Economic Statistics Administration; Washington, D.C.; 1975.

United States Department of Commerce; White House Conference on Balanced National Growth and Economic Development; Issues of Minority Business Development; Washington, D.C.; January, 1978 . 